\title{
The Development of Asian Sport Industry 亞洲運動產業的發展
}

\author{
Shu-Chen HUANG
}

Tunghai University, TAIWAN

Hsiu-Ching CHANG

Chia Nan University of pharmacy \& Science, TAIWAN

\author{
黄淑貞 \\ 台灣東海大學體育室 \\ 張秀卿 \\ 台灣嘉南藥理科技大學休閒保健管理系
}

\begin{abstract}
Asia has been playing an important role politically and economically in the world and its influence will extend in the $21^{\text {st }}$ century. At the meantime, sport industry is also booming in the Pacific Rim in terms of the concept of global village. Sport industry was a $\$ 213$ billion USD business and ranked the sixth major industry in the United States in the $20^{\text {th }}$ century. The global sport business has already exceeded $\$ 500$ billion USD in the new millennium (Street \& Smith's Sports Business Journal, 1999). John Cappo, International Vice President at International Management Group (IMG) indicates that the World Cup Korea/Japan 2002 and the awarding of the Olympic Games to Beijing 2008 is a further testament of the increased proliferation of sports marketing in Asia. These countries and governments use the sports marketing platform to provide a window to the world, promote their countries, business and cultural exchange. This support and commit will further add to the development and growth of the sports marketing industry. There is no doubt about that the sport industry is an economic behemoth and it is creating unlimited potential opportunities for all kinds of business. The impact of sport business is increasing in Asia when the values of health and leisure are more emphasized. In addition, it is critical to understand the development of sport industry in Asia as the world trade is more globalized and sport business is more internationalized. Therefore, the purposes of this paper are to: 1) introduce the development of Asian sport industry in China, Japan, Korea and Taiwan as the examples, 2) foresee the future development of sport industry in $21^{\text {st }}$ century.
\end{abstract}

Key words: sport industry, Asia

\section{摘 要}

亞洲一直是世界經濟及政治的一個重要角色, 它的影響力已延伸到21世紀。在世界村的觀念下, 亞太地區的運動產業正在蓬 勃發展。二十世紀的美國, 運動產業是總值2,130億美元的第六大產業, 而在這新的世紀裡, 全球運動產業的總值已經超越5,000 億美元, IMG的國際副總裁John Cappo 指出2002年日本及韓國的世界盃及2008年的北京奧運證實了運動產業在亞洲的發展。這 些國家及政府利用大型國際運動賽事來為本國宣傳, 同時也促進文化及經濟的交流, 像這些國家的付出及支持, 更加速運動產業 的發展。無疑的, 運動產業這隻經濟巨獸已創造出無限的商機, 尤其當健康及娛樂的價值在亞洲地區日益受到重視之際, 運動產 業的影響力也就與日俱增。在目前貿易全球化及運動商業國際化之時, 了解亞洲國家的運動產業就顯得相當重要了。鑑此, 本研 究的主要目的是以中、日、韓、台為例, 介紹亞洲的運動產業並預測二十一世紀該產業的發展。 


\section{Introduction}

At the end of the last century, the Sport Industry was a \$213 billion USD business and ranked the sixth major industry in the United States (Street \& Smith's Sports Business Journal, 1999). By 2005, the Sport Industry has experience tremendous growth and is estimated to be a $\$ 350$ billion industry in the United States, (Shank, Matthew, Sports Marketing, 2005). That is more than $50 \%$ growth in five years. . There is no doubt that the Sport Industry is an economic behemoth and it is creating unlimited potential opportunities for all kinds of business.

The global sport business had exceeded $\$ 500$ billion USD at the turn of the new millennium (Street \& Smith's Sports Business Journal, 1999) With the improvement of the living standard, health and leisure are appreciated more around the world. The popularity of sport participation has been increasing tremendously especially in the developing countries. Consequently, the Sport Industry has been booming along with the sport population. The development of Sport Industry and its increasing impact in Pacific Rim countries will be introduced and analyzed in this paper. The purposes of this paper are to: 1) introduce and analyze the development of Sport Industry in China, Japan, Korea and Taiwan, and 2) discuss development of Sport Industry in the foreseeable future.

John Cappo, International Vice President at International Management Group (IMG) indicates that the award of World Cup of Korea/Japan 2002 and the Beijing Olympic Games 2008 is a testament of the increased proliferation of sports marketing in Asia. These Asian countries use the sports marketing platform to provide a window to the world, promote business and cultural exchange. This support and commit had further added to the development and growth of the market of Sport Industry.

\section{Categories of the Sport Industry}

Since each countries has different economic and culture background, the easiest way to understand the components of the Sport Industry is to classify according to the researchers' views of each countries. The researches quoted in this paper are (Cheng, 2000, Harada, 1999, Kim, 2000) and Yam, 2000. In China, the Sport Industry was categorized into 6 segments which include: 1) fitness, 2) sport entertainment, 3) sport training and consulting, 4) sport tourism, 5) sport agency, and 6) sport lottery (Yam, 2002). In Korea, Sport Industry is the economic activities in sport and its related product/ services which creates added value through production and distribution. According to the special characteristics, the Korean Sport Industry can be classified into: 1) sport facility businesses, 2) sport product businesses, and 3) sport service businesses (Kim, 2000). Harada indicates that Japan's traditional sport industry was classified in three basic elements 1) sport product, 2) sport facility \& space, and 3) sport information. He further explained that the composite segments being developed after 1970 including 1) sport-related retail, 2) facility \& space management, and 3) professional sport. In Taiwan, sport industry can be segmented in 1) sport performance, 2) sport production, and 3) sport promotion.

According to Table 1, China's view in segmenting Sport Industry is toward sport service industry, which can make commercial profits. Based on this perspective, sport goods segment is not included in China's sport industry category. However, for the rest of the selective nations, sport production is the first segment in forming the Sport Industry at the early stage. The category of four different Sport Industries can be explained by the positioning of core segments and extended segments as Table 1. 
Table 1. Categories of the Sport Industry.

\begin{tabular}{ll}
\hline COUNTRY & SEGMENTS \\
\hline China & physical fitness \\
& sport entertainment \\
& sport training and consulting \\
& sport tourism \\
& sport agency \\
& sport lottery \\
& sport product \\
Japan & sport facility \& space \\
& sport information \\
Korea & sport product \\
& sport facility \\
& sport service \\
& saiwan \\
& sport product \\
& sport performance \\
& sport promotion \\
\hline
\end{tabular}

\section{Size of Sport Industry}

According to Yam's study (2002), the total sport consumption in China was $\$ 140$ billion RMB. Kim's study (2000), the size of Korean sport industry was a USD $\$ 10.245$ billion business. The total consumption in sport product market was $\$ 559$ billion won and for the sport service market was $\$ 2690$ billion won during 19881996 in Korea. Harada indicated that it was a USD\$52.8 billion business in Japan's market. Unfortunately, there has been no analysis of the size of the Sport Industry in Taiwan. The only data can be collected is the governmental budget in sport and physical education and the total amount was about \$ 381.29 million USD in 2000 (National Council of Sport and Physical Fitness, 2000). Kim (2000) had also made the comparison of sport industry among Korea, Japan and USA (Table 2).
Table 2. Size of Sport Industry.

\begin{tabular}{|c|c|c|c|}
\hline Country & Korea & USA & Japan \\
\hline GDP & USD $\$ 4,4550$ bil. & USD\$7,636 tril. & $¥ 531$ tril. \\
\hline Sport Industry & USD $\$ 10.245$ bil. & USD 255.5 bil. & $¥ 19.389$ tril. \\
\hline Ration of GDP & $2.30 \%$ & $3.35 \%$ & $3.89 \%$ \\
\hline
\end{tabular}

Kim, C. (2000). Korean sport industry. Program of the 2000 International Sport Management Congress. Seoul: Korean Society for Sport Management.

\section{Development of Sport Industry}

\section{China's Sport Industry}

There are three development stages of China's sport industry, it includes the beginning stage (1978-1992), starting stage (1992-1997), and developing stage (1997now). The cost of national sport consumption was around $\$ 17$ billion USD in 1998 (sport goods were not included) and the average growth is 5.1\% (1992-1997).

For spectator sport markets, the average per-game attendance of National Soccer Major League A has reached 21,300 and the total ticket sale is around $\$ 12.12$ million USD. For National Male Basketball Major League A, the average per-game attendance is around 3,700 and the total ticket sales is around \$1.7 million USD; for National Volleyball League, the total attendance has reached around 500,000 and the total ticket sales is around $\$ 1.45$ million USD (China's Yearly Sport Business Statistics, 1998).

For sport goods markets, the capital size of sport goods markets has arrived around \$ 17 billion USD in 1998 (National Council of Physical Education and Sport, 1998). Besides of the basic daily living consumptions, sport good has been rated the top 6 of people's primary expenditures (12 categories and 3,300 manufactures). Regarding to the professional management service markets, there are IMG (USA), IDEA (Italy), ELITE (HK) and local PR agencies in Beijing and other big cities. Sport lottery markets were opened in 1994 and the revenues have reached $\$ 800$ million USD (table 3). High competition, unbalance development, quantity and quality of industry construction, national policies and regulations, and $\mathrm{R} \& \mathrm{D}$ are threatening China's sport industry in terms of future development.

Table 3. Sport Lottery Revenues (1995-2000).

\begin{tabular}{llllll}
\hline 1995 & 1996 & 1997 & 1998 & 1999 & 2000 \\
$\$ 150$ & $\$ 180$ & $\$ 210$ & $\$ 300$ & $\$ 500$ & $\$ 800$ \\
\hline
\end{tabular}

Currency: in million USD 


\section{Business Opportunities in 2008 Beijing Olympic Games}

China's government hosted a CEO Seminars titled "The Next decades: Enterprise Strategy Beijing Summit", which concluded four opportunities for the nation's development via Beijing Olympics including 1) the Olympic Games, 2) Beijing, 3) China, and 4) the World. Beijing Olympics play a role of catalyst in attracting/bring the world/ resources to China and promoting China to the world. Boham Dean, president of the Boham Group located in Denver, USA, who specialized in sport sponsorship and entertainment, anticipates that the business opportunity of Beijing Olympics would be thrilling because of China's huge market and unexpected potentials. The Olympic opportunities was in tourism, transportation, advertising, internet, environment protection technology, real estate, (mobile) communication, insurance, stamps, stocks, sport lottery, two million new job opportunities and sport industry related opportunities. In sum, the opportunities could be found in 1) infrastructure related ( $\$ 21.2$ billion USD), 2) logistics and business services related (\$ 4.91 billion USD), 3) sport industry related (\$4-5 billion USD), 4) tourism related. (\$1.2 billio USD) (http://www.beijing-2008.org).

\section{Threats in 2008 Beijing Olympic Games}

Although with the great opportunities in 2008 Beijing Olympic Games, there were some concern/risks that might threaten the potential opportunity of the Games. For instance, the terrorism was threatening the 2004 Athens Olympic Games, the security and insurance become the major issues for hosting the international sport events. In order to protect its core business - the Olympic Games, IOC takes out the insurance policy first time to manage the risks inherent to the Games of the XVIII Olympiad in Athens. Vancouver 2010 will also be applied under the same policy. (IOC Press Release, 2004). The infection problems of SARS, H5N1 (an infectious disease of chickens) also scare the public. Intellectual Property Rights protection is another concern of international corporations. In addition, the uncertainty situation of Taiwan's independence problem may also claim warfare in Asia.

\section{Japan's Sport Industry}

Hora (1992) explained the development of Japan's sport industry can be divided in 6 periods and there are 1) beginning (1880-1940), 2) expanding (1950-1960), 3) highly developing (1960-1970), 4) maturing (1970-1980), 5) transiting (1980-1990), 6) the secondary growing (19902000) period. In the beginning period, modern sport was introduced to Japan; in expanding period, sport facilities have been built tremendously; the concept of leisure sport has formed in the highly developing period; participation of golfing and skiing has grown rapidly; the business of health clubs and resorts were booming during 19801990; the trend of professionalism and commercialization in sport has promoted the secondary growth period in Japan's sport industry.

\section{Korean Sport Industry}

With the positive impacts of 1986 Seoul Asian Games, 1988 Seoul Olympic Games, and 2002 JapanKorea World Cup, the sport industry in Korea has been developing well under the overall economic recovery in Asia. Sport service business is playing the important part in the $21^{\text {st }}$ century in Korea and it includes professional sport, amateur sport and sport events. All three sport businesses worth total of 348 million dollars. The size of professional sport market in Korea is 246 million dollars including car racings. The total number of spectators for professional games is more than 20 million in 2001 (Kim, 2004).

The Sport Industry in Korea has been growing constantly each year. In 2007, the Sport Industry took $2.58 \%$ of GNP. It is lower than the Manufacture (5.6\%) but higher than Agriculture (1.4\%) and mining (1.75\%) The Sport Industry has been growing since 1990 and will grow at a bigger step in the near future.

The Sport Industry in Korea can be divided into three category: Equipment, Manufacture and Service. The Equipment took $15.9 \%$ or the Sport Industry while Manufacture took $38.7 \%$ and Service sector took 45.4\%. The Horse Race took $74 \%$ of the Service sector. Meanwhile, the total spending on armature took $26 \%$ of the whole Sport Industry. 


\section{Development of Taiwan's Sport Industry}

Except for the public funded sport activities, Taiwan's sport industry can be summarized as the following:

- The impact of pursuing quality leisure life and health has causing the rapid development of healthrelated club business.

- The impact of professional sport including baseball, basketball, and bowling, has promoted the popularity of leisure sport.

- The impact of promotion strategy applied by sport product corporations have increasing the participation number of sport such as jogging, walking, extreme sport, street ball, basketball and so forth.

- Due to the scandal of gambling in professional baseball and ineffective marketing strategy, player's salary has been cut more than 50\% (average monthly salary was about USD \$ 16,000 and USD \$6,450 at present time); TV broadcasting right has also decreased because of low attendance and interest. But after Taiwan's baseball won the third place at World Baseball Championship in Taipei and qualified for 2004 Athens Olympic Games, which has encouraged two professional baseball leagues to merge as one. The professional baseball market is re-activated and the ticket sales has increased 158\%(www.cpbl.com. tw)

- a new scandal of throwing (intentionally losing) games of professional baseball was under investigation (2009-2010). The impact of this scandal still remains to be seen.

- Due to the economic influence, professional basketball has locked out.

- $70-80 \%$ of sport goods production made in Taiwan were for exportation (Won, 2001). For instance, more than 4 million sport shoes were exported annually. Due to the recession, the market has been decreased about 30\% (Chen, 2001; Chen, 2000).
- The internet user population in Taiwan is about 5-6 million and the amount of internet advertising market was worth \$ 25.8 million USD (Chen, 2000). However, sport sites have been influenced and decreased because of the impact of internet industry.

\section{Observations}

Asian sport industry will be influenced by the global trends of sport and it is imperative to cope with the trends for future development. There are:

- The continuous growth of major international mega sport events such as 2010 Guangzhou Asian Games in China.

- The issues of gender equality, culture, special population, minority, customization of international sport, TV broadcasting right, sport marketing and corporate sponsorship will be the focus in sport industry in future.

- Leisure sport and health lifestyle will be the main issues for the people to concern.

- Doping, over-commercialization, gambling and ethical issues will be the threats to the Sport Industry.

\section{Summary}

The future of Sport Industry has unlimited potential but it depends very much on whether these countries can cooperate with each other in the development of this industry. The spectrum of the cooperation will cover a wild range from investment, new technology and economic cooperation.

The uncertainty of future is like the result of sport game that is too difficult to predict. However, it is imperative to minimize the impact of uncertain factors in order to make better control of the future. For the best result of sport industry in the future, sport leaders should be like a coach of a sport team who has to train hard, collect necessary information and plan the strategy in order to win the game. 


\section{References}

Ashton, C. (2002). China: Opportunities in the business of sport. London: Sport Business Group. p. 60.

Chelladurai, P. (2001). Managing organizations for sport \& physical activity: A systems perspective. Scottsdale, AZ: Holcomb Hathaway.

Cheng, S. T. (2001a). A study of the bidding model for the modern Olympic city (1992-2000). Project Report (unpublished). National Counsel of Science, Taipei, Taiwan.

Cheng, S. T. (2001b). Principles and practice of sport marketing. Taipei: Han-Wen Publisher.

Cheng, S. T. (2002). Introduction of sport management. Taipei: Whang-Tai Publising.

China's Yearly Sport Business Statistics. (1998).

China's Yearly Sport Business Statistics. 1995-1998.

Graham, S., Goldblatt, J.J., \& Delpy, L. (1995). The ultimate guide to sport event management \& marketing. Chicago: Irwin Publishing Group.

IOC Press Release, 2004/4/27.

Pao, M. S. (2000). Sport industry. Beijing: People's Physical Education. p. 146.
Preparatory Office, Organizing Committee of the 2008 Olympic Games, Beijing 2001; Media Content Asia Pacific. Hong Kong, 2000.

Plunkett Research, Ltd.(2009). Plunkett's Spots Industry Almanac 2010, from http://www.plunkettresearch.com/ Industries/sport/sportStatistics/tadid/273/Default.aspx

Shank, M. (2005) Sports Marketing. Upper Saddle River, NJ: Pearson Prentice Hall

Shone, A. (2001). Successful event management. NY: Continuum Books.

Tsai, J. W., \& Chao, C. J. (2001). Sport sponsorship: Win-win strategy. Beijing: People's Physical Education. p.360.

Yang, F. (2001, Aug.). The evaluation of social and financial impacts on 2008 Beijing Olympic Games. Investing China, p. 17. http://www.beijing-2008.org

\section{Correspondence}

Corresponding anthor: Shu-Chen Huang (黄淑貞) Address: P.O.Box 983 Tunghai Uinversity

NO. 181, SECTION 3,

TAICHUNG PORT ROAD,

TAICHUNG CITY 40704, TAIWAN, REPUBLIC OF CHINA

Telephone: 04-24515346, 0988-127198

E-mail: jenna@thu.edu.tw, jennahu@yahoo.com 